\title{
写真画像を用いた簡易三次元インテリアイメージ 作成システム
}

$\begin{array}{llllll}\text { 正員 松 } & \text { 崎 } & \text { 吉 } & \text { 衛 } & \text { (日 } & \text { 立) } \\ \text { 非会 今 } & \text { 井 } & & \text { 薫 } & \text { (日 } & \text { 立) } \\ \text { 正員大 } & \text { 成 } & & \text { 尚 } & \text { (日 } & \text { 立) } \\ \text { 非会員 杉 } & \text { 本 } & \text { 佳 } & \text { 弘 } & \text { (日立CS) } \\ \text { 非会員 上 } & \text { 村 } & & \text { 護 } & \text { (日立 CS) }\end{array}$

\author{
User Friendly 3-D Interior Image Generation System Using Photograph Image \\ Kichie Matsuzaki, Member, Kaoru Imai, Non-member, Hisashi Ohnari, Member (Hitachi, \\ Ltd.), Yoshihiro Sugimoto, Non-member, Mamoru Kamimura, Non-member (Hitachi Com- \\ munication System Inc.)
}

A graphic model generation system for house interiors has been developed. The system generates an interior image which fits a user's idea. The system includes an interior picture database which can be accessed interactively using key words to select a desired picture. The system generates a graphic model by mapping part images included in the selected picture on a specified room structure. The dimensions and view points of the picture in the database and the specified room are different. Therefore, the graphic model is three-dimensional. To construct a three-dimensional parts image database, a picture image is recognized by a monocular vision algorithm, and normalized images, sizes, and locations in a room space of the picture are calculated. Using these data, part images can be mapped on a specified room structure. The system was utilized in a home electronics presentation system to generate a photorealistic environment model. This environment model helps in appearence design evaluation and setting of product specifications to fill customer requirements.

キーワード：ヒューマンインタフェース, 環境モデル, 三次元認識

\section{1. まえがき}

計算機のグラフィック性能の向上に伴い，計算機と 人、およひ計算機を介した人と人との对話システムに おいて，グラフィカルなインタフェースの利用が增大 している(1)-(s)。グラフィカルなインタフェースは, 梘賞的感性に訴える情報の提供や，人のバターン軒識 能力を利用するうえで極めて有効であるが，ダラフィ ックモデルの作成に多大の工数を要するという䦓題が あり，この工数削隇が課題となっている。

ここでは，インテリアを対触に，概念的イメージに 迺合するグラフィックモデルを简易に作成するシステ ムについて述べ。本システムは,グラフィックモデ
ル作成の対象とする部星の搆造が入力され，インテリ ア写真のデータベースの中から，ユーザのもつ概念的 イメージに近い写真が指定されると，写真に存在する 個々の物体の画像を部屋の践造に合せてマッピングし たグラフィックモデルを作成するものである。これに より，写㭟の印象に近いインテリアイメージを作成表 示できる。

このためには，写真から奶出した物体の画像に，マ ッピングに必要な情報を付加すると共に，その情報を 用いて任意構造の部屋にマッピングする方式を開発す る必要がある。この情報には物体の形状，位珇が含ま れ，これらの情報を1枚の写真から得るには，写真画 像を三次元謥識する必要がある。 
本論文では，初めに本システムの用途と要件を示 し，次にマッピングに用いる画像データベースの榑造 とマッピングの方法について述くる。更に,コンピュ 一タビジョンにおける単眼視手法により, 写真に存在 する物体の形状，位置を求める方法について述べる。 最後に，本システムを家庭電気機器プレセンテテショ ンシステムへ適用した結果について評洒を行う。

\section{2. インテリアイメーシの作成方式}

〈2・1〉対話プロセスとシステム倩成 本システ ムのねらいは, 部屋の構造を入力するだけで, その部 屋に対する各種のインテリアイメージを箱単に作成て きるようにすることである。用途としては，新築/改 修する室内の完成予想イメージ作成, 家具や機器のデ ザインを評価する際の使用環境イメージの作成などが ある。このようなシステムへの要求は次のようにな る。

(1) ユーザのインテリアに対する础念的イメージ に適合するグラフィックモデルを，構造を入力した部 屋について容易に作成できる。

（2）個々のインテリア構成物を指定しなくても, コーディネートされたインテリアのグラフィックモデ ルが自動作成できる。

このような用途におけるユーザと本システムとの対 話プロセスを図 1 に示す。ユーザは，作成しようとす るインテリアの概念的イメージを表現するキーワード をメニューの中加ら指定する。イメージ㺃索部は指定 されたキーワードに適合するインテリア写真を，棈造 化イメージデータベースの中から複数枚蚞索しューザ に示す。ユーザは提示された写真の中から最も自分の 概合的イメージに近いものを選択する。イメージモデ 儿作成部は，構造化イメージデータベースに保持され ている写真に存在する個々の物体の画像を，あらかじ め入力されている部屋椪造データに合せてマッピング
し，選択された写真の印象に近いインテリアイメージ を作成表示する。

棈造化イメーシデータベースは，次節に示す棈成を とり，データ入力者がイメージパーツ作成部を用いて データ登録する。データ登録の処理内容は第 3 章に 示す。

部屋構造データは,インテリアイメージを作成する ユーザが部屋榑造データ入力部を用いて入力する。部 屋構造デー夕は部屋を平面の集合で表しており, 各平 面を部屋要素と呼ふ。部屋要素は夕イプと位圆形状が 指定される。部屋要费のタイプは，榑造化イメージテ 一タベースのパーツタイプに対応するものである。ま た, 部屋要素の位㯰形状は三次元座標における多角形 の頂点位置で表している。壁，天井，床など，部屋の 外殷となる部分は部屋棈造データの中に指定する必要 があるが，家具などの監き物は指定しなくてもよい。

〈2・2〉符造化イメージデータバース 本システ ムは自然画像に近い高品筫なインテリアイメージの作 成をねらっているのて，写真から切出した画像を，部 屋標造データに合せてマッピングする方法を用いてい る。ここで，壁，天井，床など，部屋の外噼となる部 分は平面で棈成され，形状も部屋棈造データで指定さ れているのて，写真から切出したパターンを適切な規 則でマッピングてきる。しかし，家其，植物など，部 屋の内部に置かれる物は複雑な形状をしており，1枚 の写真から形状を復元するのは困難である。そこで, これらの置き物は写真画像が描かれた平板として报 う。この平板を図 2 に示すように, 部屋棰造データて 指定された室内に配置することにより，ある程度の視 点変更が可能な擬似三次元グラフィックモデルが作成 てる。

このような写真画像のマッピングを行うため，本シ ステムはインテリア写真を図 3 に示すように構造化イ メージテータベースと呼が形式で保持する。デーダ

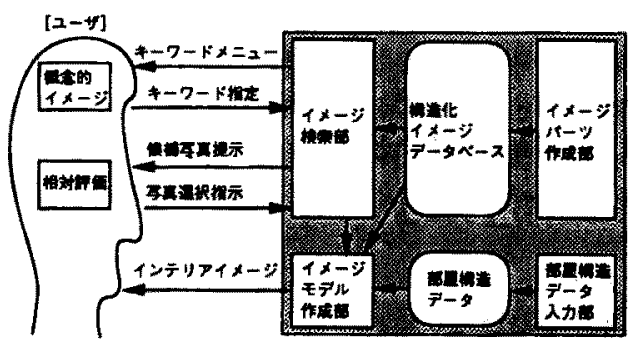

図 1 スーザと本システムの対話プロセス Fig. 1. Interaction process of a user and the system.

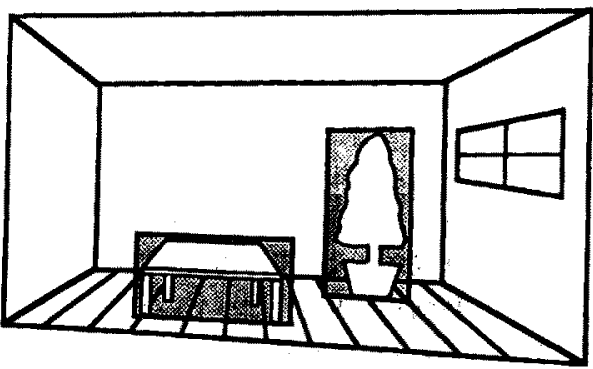

図 2 三次元プレートモデ

Fig. 2. Three-dimensional plate model. 
ースの各項目を以下に示す。

（1）全体画像 インテリフ写真をそのまま画像 データにしたもので，作成するインテリアイメージを ユーザに指定させるための例示画像として使用する。

（2）㛟案キーワード適合度 本システムては, 概念的イメージを表現するキーワードで写真を梌索す るため, 各写真にメニューに用意されているキーワー トに対する適合度が付けられている。この適合度の值 は、そのキーワードを尺度としたときの, 印象の強さ の写真間順位である。適合度の設定は,インテリア写 真を本システムに登録する際，登録者の写真に対する 印象から行う。

(3) イメージパーツ マッピングの要素となる インテリア粠成物のデータをイメージパーツと呼ぶ。 イメージパーツは画像テータと属性テータをもつ。画 像テータはすへて方形で保持する。従って，写真から 切出した画像は，次章で述べるように，まず正面から 見た形状に恣換し方形領域の中で物体画像以外の部分 に背景であることを示すコードを入れておく。また， 陰面のため欠落している部分は, 画像編集ツールを用 いて可能な箸囲て復元しておく。

イメージパーツの属性データは画像データをマッピ ングする際に使われる情報であり，以下の要素が ある。

(i) パーツタイプ インテリアイメージを作成 する部屋棈造データと,イメージパーツとのマッチン グをとるためのタイプを示す。

（ii）実物寸法 写真加ら推定した物体の寸法で あり，写真とは構造の異なる部屋にイメージパーツを マッピングする際のスケーリングに用いる。

（iii）実物位置 部屋の外殼となる部分のマッピ

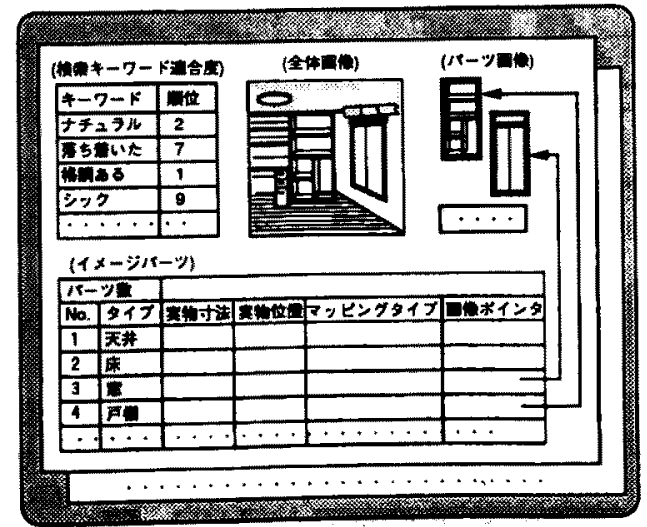

図 3 構造化イメージテータベース

Fig. 3. Structural image detabase.
ング位置は部屋槽造データから決定できるが，部屋䅦 造データにない雷き物の配置場所は部屋粠造データか ら決定できない。そこで，写真における路き物の位置 を保持しておき，配置決定に用いる。

(iv) マッピングタイプ マッピングタイプを大 別すると，部屋の外湸となる部分のように部厔構造デ 一タで位置が指定されるものと，置き物のように写真 に扔ける位置と部屋構造テータを参照して位置が決定 されるものがある。また，位犆が指定されているもの についても，画像デー夕をそのまま㹡大縮小してマッ ピングするもの，パターンに周期性があり繸あるいは 横方向に綝返してマッピングするものなどがある。こ れらのマッピングタイプの指定である。

このような構造化イメージデータベースを用いるこ とにより，部屋構造テータが入力されれば，インテリ アイメージを作成することができる。

〈2・3〉イメージパーツのマッピング方式

(1) イメージパーツの娭索 1枚のインテリア 写真の中に, 部屋粠造データで指定された部屋要素の タイプに対応するイメージパーツがすべて含まれてい るとは限らない。例えば，部屋構造データには空があ るが，選択された写真には空がないことがある。そこ で本システムは，図4に示すようにグラフィックモデ 儿作成の際，まず選択された写真に含まれるイメージ パーツを用いるが，選択された写真に部屋構造データ

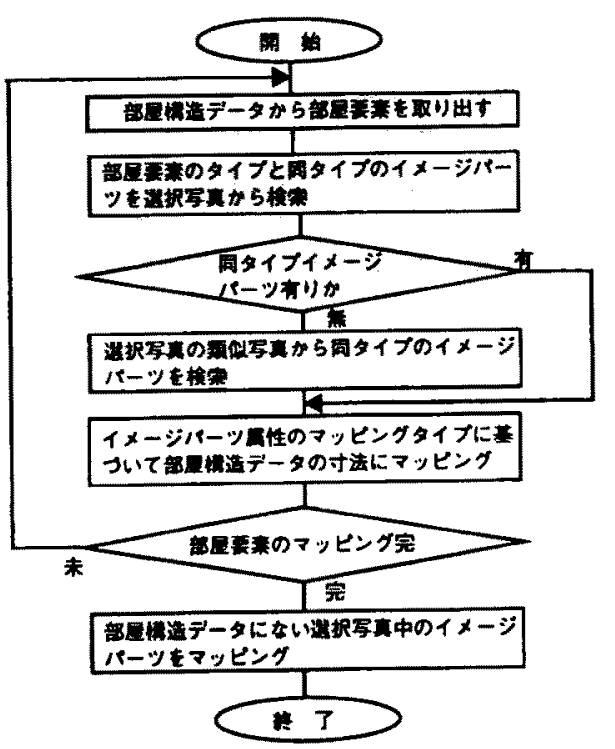

図41メージパーツのマッピング手順 Fig. 4. Flow of image-parts mapping. 
て指定されている部屋要絭のタイプに対応するイメー ジパーツがない場合は，他の写真に含まれるイメージ パーツを用いる。

このため，まずユーザの概念的イメージを表現する 言葉として指定された検索キーワードに対する，検索 キーワード適合度を参照し，指定された写真と嗃合度 の近いものから䐓に, 必要なタイプのイメージパーツ の有無を調べる。従って, 使用されるイメージパーツ は，そのときの検索キーワードによって異なる。この ようにして，選択された写真が室内の部分的なシーン であっても，グラフィックモデル全体を作成すること ができる。

（2）外殼パーツのマッピング 暨，天井，床な ど, 部屋の外款となる部分は, 部屋棈造データにおい て位䈯形状が指定されているので，これらに対するイ メージパーツのマッピングは, パーッ画像を指定され た寸法形状に拡大，縮小することで行える。ここで， パーツ属性のマッピングタイプとして絽返しが指定さ れているものは, 部屋権造データで指定された位㯰形 状と，パーツ属性で指定されたパーツ画像の実物寸法 を用いて，周期的パターンを生成しマッピングする。

（3）置き物パーツのマッピング 部屋構造デー タでは, 家具などの置き物について指定していないこ とが多い。このように, 構造化イメージデータベース では選択された写真のイメージパーツとなっている が, 部屋構造データには指定されていないものについ ては, 部屋の中への配置を自動的に行う。この配置 は,マッピングタイプで指定された配置方法に対応す るプログラムが, 部屋構造データと, パーッ属性の実 物寸法，実物位㯰のデータを参照して決定する。

表 1 にこの配置方法の種類を示す。例えば，植物の イメージパーツについて, スケーリングタイプと位置 決めタイプを部屋寸法に比例とし, 両方向タイプを視 線に垂直とすると, 部屋構造データで指定された部屋 に対し，もとの写真における植物と同じようなバラン スで植物が配置される。

表 1 置き物パーツ用マッピングタイプ Table 1. Mapping types for layout undefined image-parts.

\begin{tabular}{|c|c|}
\hline 項 & 㮔 \\
\hline スケーリング & $\begin{array}{l}\text { ・部壁寸法に比例 } \\
\text {-物体寸法保存 }\end{array}$ \\
\hline 位目 & 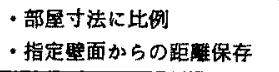 \\
\hline 面方向 & $\begin{array}{l}\text { ·写真の面方向保存 } \\
\text { •視線に萁淔となるよう可変 }\end{array}$ \\
\hline
\end{tabular}

\section{3. イメージパーツの作成}

柾造化イメージデータベースは，インテリアイメー ジを作成しようとするユーザの多㴍な教求に底えるた め, 睢富な種類のインテリア写真を畜程する必要があ る。このような多数の写真を本システム棈箱のために 新たに撮影することは奞しく，摄影条件の不明な既存 军真からイメージパーツを作成することになる。イメ ージパーツ作成の中心となる処理は，対象とする物体 を方形平板て表したときの各頂点の室内三次元空間に おける位置を求めることであり，ここでは単眼視によ る三次元㒛識の手法を使用して行う。このイメージバ 一ツの作成方法を以下に示す。

\section{〈3・1〉カメラパラメータと基準面位置の決定}

カメラの位置や焦点距離などのカメラパラメータが 既知ならば，対象の形状に関する拘束条件を用いて三 次元形状の復元ができるが(4)，本システムで使用する 写真は撮影条件が不明なので, カメラパラメータの推 定を三次元形状の復元と同時に行う必要がある。カメ ラパラメータの推定方式は各種提案されているが，1 ンテリア写真を対象とする本システムではテストパタ ーンを用いる方式(5)(6) は適用てきない。また，直交す る3 組の平行線のバニシングポイントを用いる方式(7) は適用可能な写真が少ない。そこでここでは空や暨 など，通常の写真で多く見られる長方形形状の条件を 使用する。なおここではカメラ光学系のりがみや， 垂直あるいは平行とみな寸物体自体のゆがみなど，多 くの誤差要因を考慮していないが，イメージパーツに 要求される計湘精度はあまり高くないので, 実用上吘 容されると考えている。

図 5 は写真内の一つの面のカメラ塺栖系における位 置を決めるモデルを示すものである。ここで面の位 羁の票出に長方形形状の条件を用いるのて, 長方形て あることが明白な物体を写真の中から選択する。この

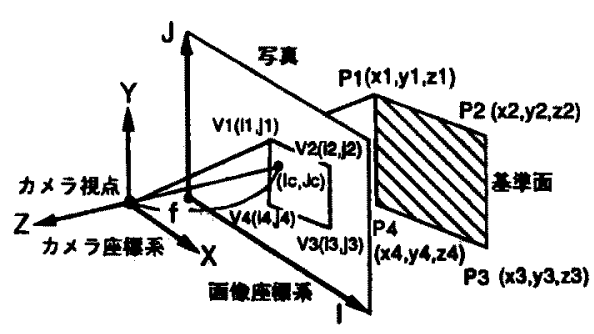

图 5 基準面復元用カメラモデル

Fig. 5. Camera geometry for recovery of a base plane. 
ような, 最初にカメラ座標系における位㯰を求める面 を基準面と呼ふ。図 5 に示すモデルにおいて，基準面 をカメラ座標系のベクトル $P_{1}, P_{2}, P_{3}, P_{4}$ を頂点とする 長方形で表すと, 基準面は, 向かい合う 2 組の辺が平 行で長さが等しく角は直角なので，(1)式の関係が成 立する。ここで，Kはスケールファクタであり, 距 離が比較的正しく推測できるものから指定する。

$$
\left.\begin{array}{l}
P_{2}-P_{1}=P_{3}-P_{4} \\
\left(P_{2}-P_{1}\right) \cdot\left(P_{4}-P_{1}\right)=0 \\
\left|P_{2}-P_{1}\right|=K \\
\text { (“"”: ベクトル内積演算子) }
\end{array}\right\}
$$

また，図 5 のモデルにおいいて基準面の 4 頂点は，画 像座標系では $V_{1}, V_{2}, V_{3}, V_{4}$ に投影されている。各頂 点の画像座標における位置とカメラ座標系における位 㯰の関係は以下のようになる。

$$
\begin{aligned}
& \frac{x_{1}}{i_{1}-I_{c}}=\frac{y_{1}}{j_{1}-J_{c}}=\frac{-z_{1}}{f} \\
& \frac{x_{2}}{i_{2}-I_{c}}=\frac{y_{2}}{j_{2}-J_{c}}=\frac{-z_{2}}{f} \text {. } \\
& \frac{x_{3}}{i_{3}-I_{c}}=\frac{y_{3}}{j_{3}-J_{c}}=\frac{-z_{3}}{f} \\
& \frac{x_{4}}{\dot{i}_{4}-I_{c}}=\frac{y_{4}}{j_{4}-J_{c}}=\frac{-z_{4}}{f}
\end{aligned}
$$
ここで, 4 頂点の位置 $x_{1}, y_{1}, z_{1} \sim x_{4}, y_{4}, z_{4}$ は 12 個で あるが, 画像中心の位置 $I_{c}, J_{c}$ と画像座標の原点から カメラ視点までの距離 $f$ も不明なので, 未知数の合 計は 15 個となる。

この解を求めるため, 基準面以外の拘束条件とし て, 基準面に垂直あるいは平行な直線を使用する。イ ンテリア写真には, 壁, 天井, 床や, 直方体の机, 户 棚の縁など, 直あるいは平行関係が推測できる物体 が多い。これらの物体から抽出して拘束条件として使 用する直線は，本数や関係が写真によって異なるの で，(1)，(2)式とは別に用いる。すなわち, まず $I_{c}, J_{c}$ を仮定し, 未知数を 13 個として連立方程式を解 き, 得られたカメラパラメータを用いて拘束条件とす る直線と基準面の角度を求め, 推測値との愦差を計算 する。この誤差 2 乗和を $I_{c}, J_{c}$ を変化させながら評価 し, 誤差 2 乗和が最少になる $I_{c}, J_{c}$ を求め, このとき の連立方程式の解からカメラパラメータと基準面の位 瑥を求める。

〈3.2〉 イメージパーツ原画の切出し 基準面の 位置を求めた後, イメージパーツ原画となる長方形領 域の切出しを次の上うに行う。

まず，イメージパーツ作成者が，位置が既知である
平面内の点, あるいは平面の方向成分の值を合計 3 個 指定することにより，イメージパーツを含む平面の方 程式を求める。インテリアを構成する物体間の角度は 90 度など規則的なことが多いので，イメージパーツ 作成者は，基準面に対するイメージパーツの面方向を 写真から推測することができる。また, 基準面は位置 が求められているので，基準面に接続している点の位 置も求められる。

イメージパーツを含む平面の方程式が得られたら， 本システムはその平面に透視した方形ウィンドウを発 生させる。ここで，方形ウィンドウの方向は，方形の 1 辺を指定された面に平行になるように定める。イメ ージパーツ作成者が，この方形ウィンドウの位置およ びサイズを対象物に合せて調節し設定することによ り，この 4 頂点で囲まれた領域をイメージパーツ原画 として切出すことができる。

この操作を綠返すことにより，必要なイメージパー ツ原画を切出すことができる。なお，この過程でイメ ージパーツを含む平面は位置が求まるので, 基準面と 同様に次のイメージパーツを求めるために使用するこ とができる。

〈3.3〉パーツ画像データ作成 イメージパーツ 原画に対し以下の処理を行い，画像デー夕を作成す る。処理例を図 6 に示す。

(i) 正面画像作成 写真画像加切出したイメ ージパーツ原画を，イメージパーツ平面に投影した方 形画像に変換する。

（ii）背景除去 物体輪郭が方形でない場合，イ メージパーツ原画に対し, 物体以外の背固部分の画像

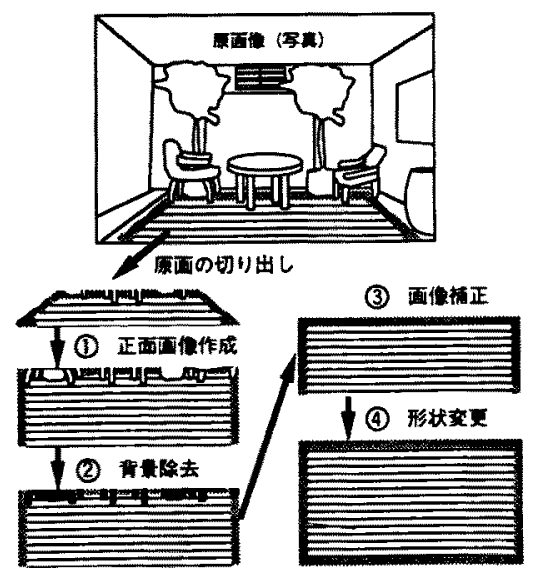

図 6 パーツ画像データの作成

Fig. 6. Generation process of image-parts data. 
を背景コードに置き換える。従って，画像データとし ては方形でもつが，背景コードの領域は表示しないよ うにできる。物体と背景の分踓はカラーセグメンテー ション,およびエッジ検出で行う。

(iii）画像補正 一般のインテリア写真では多く の物体が重なって存在するので，イメージパーツ原画 ては物体画像の一部が陰面となっていることが多い。 この陰面部を, 物体画像の他の部分を用いて復元する 必要がある。この復元は画像編集ツールのカットアン ドペースト機能を用いて手作業で行う。従って, 陰面 部が大きく復元工数が多大になる物体は，重なってい る物体をまとめて一つのイメージパーツとしたり， 1 メージパーツにしないことになる。

（iv）形状変更 復元しようとする物体画像がイ メージパーツ原画の方形より大きい場合は, イメージ パーツの画像サイズを変更する必要がある。例えば写 真に一部分しか写っていない物体のイメージパーツ画 像を作成するためには，まず，画像サイズを物体全 部が入る程度に㹡大した後, 上記画像補正処理を 行う。

〈3.4〉パーツ属性指定 図 3 に示したイメージ パーツの属性要素のうち実物寸法と実物位置は上記処 理の過程で求められている。従って，ここで指定する 必要があるのは, パーツタイプとマッピングタイプで ある。これらは，本システムが用意しているタイプの 中から該当するものを選択して指定する。

\section{4. 家庭電気機器プレゼンテーションシステム への適用と評価}

〈4・1〉システムの開発仕様＼cjkstart本システムを，使 用環境に適合した家庭電気機器の仕様検討をビジュア ルに行うためのシステムに適用した。このシステム は，想定するインテリアのモデルを計算機上に構築 し，このモデルを用いて，インテリアと調和した機器 の外観デザインや配置を検討すると共に，使用環境と なる空間での性能特性を評価するものである。

このシステムは特定の建築物件に対して使用される ので，指定した構造の部屋に対しインテリアイメージ を作成する必要がある。しかし，インテリアデザイン 自体が目的ではなく, 電気機器の仕様検討に用いる背 景としてインテリアイメージを作成するので, インテ リアイメージの細部にわたる正確さは要求されない。

このシステムにおける写真の検索画面を図 7 に示 す。概念的イメージを表すキーワードをメニューから 同時に二つまで指定すると，そのキーワードに対する 適合度を軸とするメッシュに，適合度の高い写真が 9
枚表示される。この画面で，検索用のキーワードを㚆 えたり，写真をスクロールさせることにより，嘅念的 イメージに近い写真を検索する。このような操作によ り写真が指定されると，この写真から作成されたイン テリアイメージの中にエアコンなどの電気機器を配置 した外権，その機器の性能特性，仕様などを図8のよ うに表示する。ここで, 機器のデザインや配置の変更 を指定すると, それに伴ってインテリアイメージが変 更される。

今回開発した構造化イメージデータベースの仕樣を 表 2 に示す。また，同一の部屋に対して幾つかの写真 から生成したインテリアイメージと，榓造や視点の異 なる部屋に対して同一の写真から生成したインテリア イメージの例を図 9 に示す。

〈4・2〉考 察 本システムは, 写真画像を利 用した擬似三次元的なグラフィックモデル作成システ ムなので，図9のように対㞘とする部屋の構造が写真 とある程度異なっていても，写真の印象を保存したイ ンテリアイメージを作成することができる。しかし， 対象とする部屋の構造や視点が，写真画像と大きく異 なるにつれて不自然さが目立ってくる。不自然さの生 じる原因とその対策をまとめると以下のようになる。

（1）光源の違い 空の位置や寸法が大きく異な ると，壁面や置き物にあたる外光の状態が不自然にな る。また，壁面などの外殸パーツのマッピングタイプ として, 繰返しを用いると,シェーディングの状態も 繰返しとなるので不自然になる。この対策としては, イメージパーツの切出しの際, 明るさの状態ができる たけ一様な領域を選ふこと，および切出したイメージ パーツ原画を画像処理してハイライトの除去 ${ }^{(8)}$ や, 明るさの均一化を図ることがある。

（2）置き物パーツの平板表現置き物パーツは

表 2 構造化イメージデータベースの仕様 Table 2. Specifications of structural image detabase.

\begin{tabular}{|c|c|}
\hline & \pm \\
\hline インテリア゙写真の種頶 & $\begin{array}{l}\text { リビングルーム: }: 25 \\
\text { 和室 }: 15 \text {, 菖室: } 15 \\
\text { 子供部屋 }: 10\end{array}$ \\
\hline 梌索キーワードの程類 & $\begin{array}{l}\text { ナチェラル，落ち着いた，格調ある、シ } \\
\text { ック、明るい、暖かい、はなか、など： } \\
21\end{array}$ \\
\hline バーッタイプの重類 & 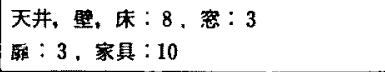 \\
\hline マッピンダタイプの種顆 & $\begin{array}{l}\text { 繅返しパターン: } 4 \\
\text { スケーリンダ: } 2 \text {, 配贯 : } 4\end{array}$ \\
\hline
\end{tabular}




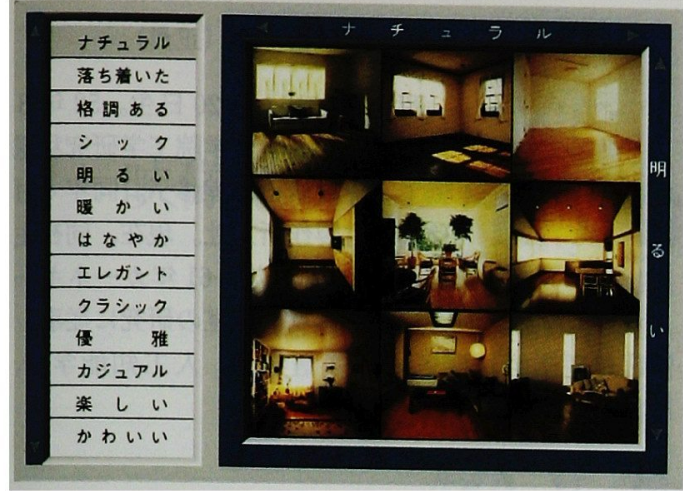

図 7 インテリア写真の検索画面

Fig. 7. Example of interior photograph retrieval picture.

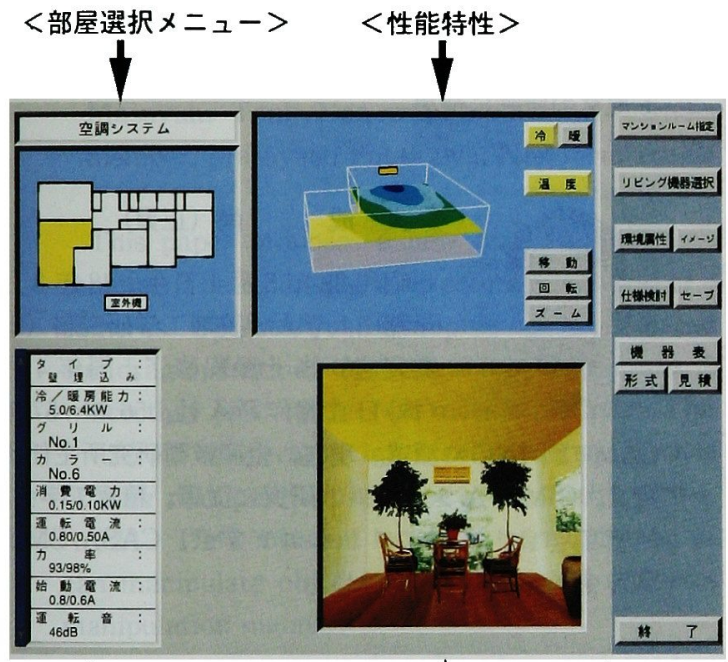

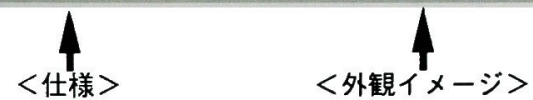

図 8 家庭電気機器の検討画面

Fig. 8. Example of home electric apparatus evaluation picture.

本来ボリュームのあるものを平板化しているので，イ ンテリアイメージの視点が写真の視点と異なるにつれ て，本来見えるべき面が見えず不自然になる。この対 策としては, 置き物パーツの配置方向を部屋に対して 固定せず，視点方向に合せて補正する方法がある。ま た，机やベッドなどの複数の平面をもつ物体は，一つ の平板で近似すると視点の違いにより極めて不自然に なる。このような物体に対しては, 一つの平板でなく 方向の異なる平面ごとに複数のイメージパーツに分割

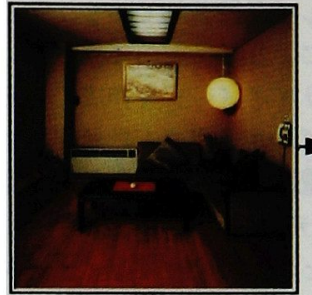

(a)写真 1
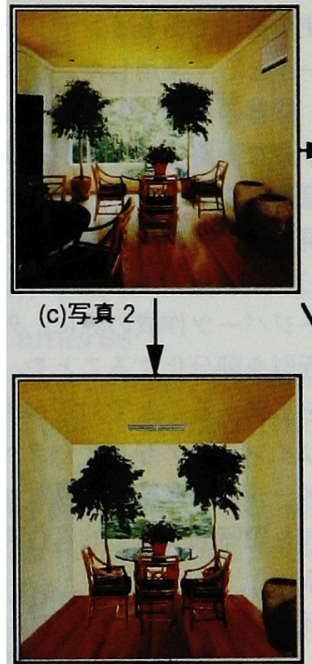

(e)部屋 $\mathrm{B} の$ インテリアイメージ

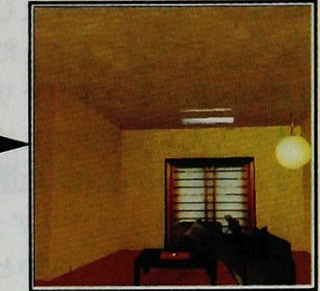

(b)部屋Aの インテリアイメージ

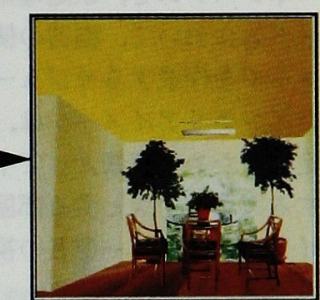

(d)部屋Aの インテリアイメージ

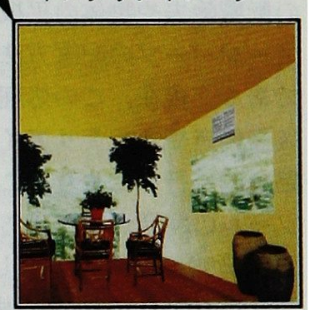

(f)部屋Aの斜方向 インテリアイメージ
部屋 $\mathrm{A}$ は图 8 〈部屋選択メニュー〉において左下の部屋, 部屋 B は同メニュー右加ら二つ目の細長い部屋

図 9 インテリアイメージ生成例

Fig. 9. Example of generated interior image.

し，このイメージパーツを一括してマッピングするこ とにより不自然さを隇らすことができる。

\section{5.むすび}

インテリアに対して概念的イメージをもつユーザ が，対象とする部屋の構造を入力するだけで，インテ リアイメージを簡易に作成できるシステムを開発 した。

本システムは, 作成するインテリアの仕様を, 概念 的イメージを表現するキーワードの指定，そのキーワ ードに適合する写真の提示, 提示された写真の中から の選択, というユーザとシステムの対話により決定す る。インテリア写真のデータベースには, 写真に存在 する個々の物体が, 平板近似した画像と属性から構成 
されるイメージパーツとして保持されており, その画 像をマッピングすることにより, 特定の部屋に対して 写真の印象に近いインテリアイメージを作成できる。

本システムを使用すれば，ユーザの工数は部屋を構 成する平面のタイプと位置形状データを入力するだけ となり, かつインテリアデザインの専門家でなくて も, ある程度バランスのとれたインテリアイメージを 作成することができる。

本システムを, 家庭電気機器プレゼンテーションシ ステムにおいて, 機器の使用環境であるインテリアイ メージを作成するモジュールとして使用した。作成し たインテリアイメージは, 機器のデザインや配置を決 定するための背景として十分な画質であったが, 使用 する写真と対象とする部屋の構造の違いや, 作成する インテリアイメージとの視点の違いが大きくなるにつ れ不自然さが出てくる。

これに対しては, イメージパーツ作成の際に, 外光 の影響除去や物体の平板近似を細分化することや，イ メージパーツの配置方法を工夫することで対策が可能 である。現在, この処理はインテリア写真データベー ス登録者やインテリアイメージの作成結果を見ながら 感覚的に行っており,これを短時間で定形的に行える ツールの開発が課題である。

本研究の実用化に関し有益な御討論をいただいた (株) 日立製作所清水工場千秋隆雄氏, 関修氏, 森 克彦氏, 同社栃木工場 鈴木秋男氏, 長谷川淳一 氏，および本研究の機会を与えていただいた同社生産 技術研究所 松本義雄博士に深く感謝の意を表する。

(平成 3 年 5 月 2 日受付, 同 3 年 8 月 6 日再受付)

\section{文 献}

（1）加藤・栗田・板倉: フルカラー絵画テータベース ART MUSEUM」, 信学技法, IE88-118, 31 (平元)

（2）加藤・下垣・藤村：「画像対話型商標・意匠データベース TRADEMARK」, 信学論, 535 J72-D-II, 535 (平元-4)

（3）笠原・岸本:「画像データベースと視考支援環境」, 情報処理 学会研究会報告人文科学とコンピュータ, 3,1 (平元)

（4）白井: パターン理解, p. 39 (昭 62) オーム社

(5) R. Tsai: "A Versatile Camera Calibration Technique for High-Accuracy 3D Machine Vision Metrology Using Offthe-Shelf TV Cameras and Lenses", IEEE J. R \& A, RA3, 323 (1987)

(6) K. Gremban, C. Thorpe \& T. Kanade: "Geometric Camera Calibration System of Linear Equations", Proc. of Image Understanding Workshop, p. 820 (1988)

(7) B.Caprile \& V. Torre: "Using Vanishing Points for Camera Calibration", Int. J. Computer Vision, 4, 127 (1990)

(8) G. Klinker, S. Shafer \& T. Kanade: "The Measurement of Highlights in Color Images", ibid., 2, 7 (1988)

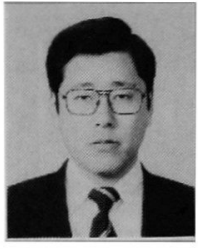

\section{松 崎吉 解 (正員)}

昭和 25 年 11 月 20 日生。 52 年 3 月慶応義塾大学大学院工学研究科電 気工学専攻修士課程修了。同年 4 月

(株) 日立製作所入社。現在, 同社生 産技術研究所に勤務。この間 60 年〜 61 年カーネギー メロン大学客員研究員。ロボット視覚の研究に従事。 情報処理学会, 電子情報通信学会, 人工知能学会, IEEE会員。

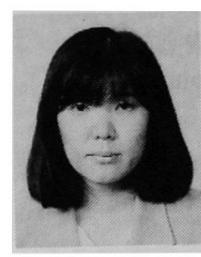

\section{今 井毫 (非会員)}

昭和 39 年 9 月 27 日生。 63 年 3 月津田塾大学学芸部数学科卒業。同 年 4 月 (株) 日立製作所入社。現在, 同社生産技術研究所に勤務。ロボッ ト視覚の研究に従事。

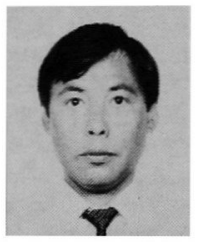

\section{大成尚 (正員)}

昭和 22 年 5 月 1 日生。 48 年 3 月 早稲田大学大学院理工学研究科 (工 業経営) 修士課程修了。同年 4 月 (株) 日立製作所入社。56 年 57 年 CAM- I , INC に派遣。現在, 生産技術研究所主任研 究員。CIM/FA システムの研究に従事。精密工学会, 経営工学会, 日本ソフトウエア学会, CASA/SME, SCS 会員。

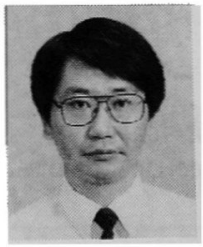

\section{杉 本 佳 弘 (非会員)}

昭和 32 年 11 月 10 日生。 58 年 3 月三重大学工学部電気工学科卒業。 同年 4 月日立通信システム(株)入 社。以降, FA 視覚の研究開発に従 事。情報処理学会会員。

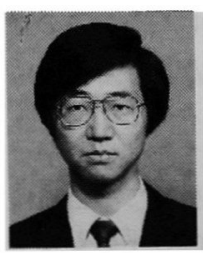

\section{上村護（非会員）}

昭和 37 年 5 月 28 日生。 60 年 3 月東海大学工学部光学工学科卒業。 同年 4 月日立通信システム (株) 入 社。受注エキスパートシステムの研 究に従事。現在, ティジタル交換器の開発に従事。 